\title{
BUFFLEHEAD USES ARTIFICIAL NEST BOX
}

\author{
by Richard S. Miller, University of Saskatchewan, Saskatoon
}

The Bufflehead, Bucephala albeola (Linnaeus), breeds throughout the wooded regions of Canada north and west of the Great Plains. Where the species is common, nearly every small pond or lake may have a breeding pair (Bent, 1925). However, because of their habit of nesting in tree holes some distance above the ground, there are few direct observations of the nests and eggs. Perhaps the most complete description of the nesting habits of this species is provided by Brooks (Bent, 1925) who studied Buffleheads in the Cariboo District of British Columbia. The nests were almost invariably located in the deserted nesting holes of flickers. They were in aspen trees, from five to 20 feet above the ground, with an entrance hole never more than 3.5 inches in diameter. The number of eggs varied from two to nine with an average of eight, and were dusky ivory in colour.

Arnold (1895, Oologist, 12:168-170) reported collecting nine Bufflehead eggs from a hole eight feet up in a Balm of Gilead tree in Touchwood Hills in the then Territory of Assiniboia. Furniss (Houston and Street, 1959) recorded several nests around sloughs four miles south of Prince Albert. The birds were flushed from holes in trees but the nests were not observed directly. Nero (with Lahrman) found a nest at Milliken Lake near Uranium City, June 25, 1960. Nero (1963) also reported a nest at Carswell Lake on July 14, 1962. The female was flushed from a nest cavity 10 feet high in a jackpine located about 40 feet above the water and 40 feet back from the water's edge. Herbert Massey (Bent, 1925) found a Bufflehead nest at Island Lake, Saskatchewan, in an old flicker hole 20 feet above the ground. The eggs lay 15 inches below the opening to the nest and the tree was 30 feet from shore. Massey collected the entire set of 10 eggs. He also took another set of 10 eggs at Montreal Lake from a nest site almost identical to the one at Island Lake. These two sets were all he found during a season's work with this species in Saskatchewan.

The present observations were made at Emma Lake, where Buffleheads are quite common during migration in spring and fall. Furniss (Houston and Street, 1959) reported that Buffleheads were common nesting birds at Emma Lake during the 1930's, but Mitchell (1924) listed this species as "not common". Mowat (1947) collected an adult and one young from a family of Buffleheads on a small pond on the shore of Emma Lake.

Broods have been observed in the vicinity of the University of Saskatchewan Biology Station on Fairy Island every year for the past five years, but no nests were observed until this year. On June 9, 1966 a female Bufflehead was seen leaving a nest box, originally installed by Wayne Davis in 1961 for his study of flying squirrels. These nest boxes are approximately six inches square and nine inches high with a hinged top and a 2.5 inch entrance hole 6.5 inches from the bottom of the box. The nest boxes have a perforated, hardware cloth bottom and are usually provided with a small amount of sawdust or litter. This particular nest box was 10 feet high in a spruce tree, 74 feet from the lake shore. When first observed, there were seven eggs. There was very little down and the eggs rested on the bare hardware cloth and could be seen from the underside of the nest box. The colour of the eggs was ivory, tinged with green. Brooks (Bent, 1925) reported that he had several times seen the eggs of this species described as "dusky green", but the eggs of Buffleheads in the Cariboo were invariably ivory with no tinge of green, and he assumed that the dusky green eggs reported by other observers were of "some species of teal". A. J. Erskine, 
Canadian Wildlife Service biologist, Sackville, New Brunswick, who is making a special study of the Bufflehead, says that he has never seen a trace of green in Bufflehead eggs himself (personal correspondence).

The nest was examined again on June 23. At this time the eggs were still visible from the underside of the nest box and it seemed advisable to provide some sawdust for insulation. The female had to be lifted off the nest. There were still seven eggs. The eggs and down were removed, a layer of sawdust was placed in the box, and the eggs and down replaced. The hen returned shortly and showed very little hesitation in re-entering the nest while observers were within about 50 feet of it. By June 26 the eggs had hatched and the nest contained seven young. On June 28 a female Bufflehead with a brood of seven ducklings was observed on the lake in the vicinity of this nest, and when the nest box was examined on
June 29 it was found that all of the young had left the nest.

Although this observation showed that Buffleheads will use artificial nest sites of this sort, one requirement seems to be that they be located reasonably close to water. Next year additional boxes will be installed in what appear to be suitable locations, in the hope that more can be learned about the nesting habits of this charming but somewhat elusive species.

\section{LITERATURE CITED}

Bent, A.C. 1925. Life histories of North American wild fowl, Part II. Smithsonian Inst., U.S. Nat. Bull. 130. 376 p.

Houston, C. S. and M. G. Street. 1959. The birds of the Saskatchewan River, Carlton to Cumberland. Sask. Nat. Hist. Soc., Spec. Publ., No. 2. 205 p.

Mitchell, H. 1924. Catalogue of Saskatchewan birds. Can. Field Nat., Special issue.

Mowat, F.M. 1947. Notes on the birds of Emma Lake, Saskatchewan. Can. Field Nat., $61: 105-115$.

Nero, R. W. 1963. Birds of the Lake Athabasca Region. Saskatchewan. Sask. Nat. Hist. Soc., Spec. Publ. No. 5. 143 p.

\section{PINE SISKIN NESTINGS IN SASKATOON, 1966}

\section{by Robert R. Cohen, University of Saskatchewan, Saskatoon}

Two Pine Siskin, Spinus pinus (Wilson), nests, apparently the first for the Saskatoon area, were found in the city on June 15 and August 15, 1966. The first was located at a height of approximately 17 feet in a White Spruce, Picea glauca (Moench) Voss, in the residential area near 7 th Street and Lansdowne, and contained eggs when first found. The nest and eggs were later photographed by J. Slimmon of Saskatoon.

The second nest was located at a height of approximately 30 feet in an American Elm, Ulmus americana L., near the Arts Building on the campus of the University of Saskatchewan. It contained fully-grown nestlings. The selection of a deciduous tree as a nest site was rather unusual, especially since there were several spruce trees within 300 yards of the elm. Adult Pine Siskins had been seen in
mid-July in the same area of the campus attempting to copulate and feeding fully-fledged young; it is quite possible, then, that the nest found on August 15 represented a second nesting for the summer by that pair of Pine Siskins.

\section{THE NORTH AMERICAN NEST-RECORD CARD PROGRAM}

asks contributors to complete and return their nest record cards to

CORNELL LABORATORY OF ORNITHOLOGY

33 Sapsucker Woods Road,

Ithaca, New York 14850 